\title{
Economic Growth, Total Factor Productivity, and Institution Quality in Low-Middle Income Countries in Asia
}

\author{
Minh Ngoc NGO' ${ }^{1}$ Loc Duc NGUYEN²
}

Received: April 19, 2020 Revised: May 03, 2020 Accepted: June 07, 2020

\begin{abstract}
The purpose of this paper is to investigate the impact of total factor productivity (TFP), institutional quality, and interactive variable between them on economic growth in 13 low-middle income countries in Asia for the period 2000-2018. The paper uses the difference Generalized Method of Moments (GMM) to explore the dataset provided by the World Bank. The empirical results show that TFP and the interactive variable positively impact on the economic growth, while the institutional determinants have a negative influence. The negative effect is explained by the weak institutions in these low-middle income countries. The findings of the study suggest two points. First, the government should continue to improve TFP, which is associated with the application of technical advances, technological innovations, improvement of management methods, and skilled workers. Second, far more important, is that the authorities should pay special attention to implement institutional reform and strengthen the governance in the future. The successful experiences from Japan, Korea and Singapore will help other governments in Asian low-middle income countries to build developmental state. Probably, the developmental state actively interfere in the market to promote and realize the development goals. By doing so, these economies might overcome the so-called "middle-income trap".
\end{abstract}

Keywords : Institutions Quality, Economic Growth, Total Factor Productivity, Asian Countries.

JEL Classification Code: A12, B22, C23.

\section{Introduction}

Promoting economic growth to improve people's living standards is the top goal of most governments around the world. The fact of raising productivity in developing countries through improving the efficiency of capital, labor and other inputs is one of the appropriate solutions in the current situation because they are often confronted with the limitation of capital source. It can be seen that research on growth is still a topic of interest and debate among researchers. Theoretically, TFP was mentioned from neoclassical growth model, then further studied through endogenous growth

${ }^{1}$ First Author and Corresponding Author. Lecturer, Faculty of Business Administration, Industrial University of Ho Chi Minh City, Vietnam [Postal Address: No. 12, Nguyen Van Bao Street, Ward 6, Go Vap District, Ho Chi Minh City, 727900, Vietnam] Email: ngongocminh@iuh.edu.vn

${ }^{2}$ Faculty of Business Administration, Industrial University of Ho Chi Minh City, Vietnam. Email: nguyenducloc@iuh.edu.vn

(c) Copyright: The Author(s)

This is an Open Access article distributed under the terms of the Creative Commons Attribution Non-Commercial License (http://Creativecommons.org/licenses/by-nc/4.0/) which permits unrestricted noncommercial use, distribution, and reproduction in any medium, provided the original work is properly cited. theory. Both of these theories identify that TFP and the factors that impact TFP play an important role in maintaining long-term growth. However, the institutional factor has not been formally considered for its effect on TFP growth and economic growth in these two theories.

The new school of institutional economics argued that institutions are the core factor affecting the efficiency of the economy. North (2000), a prominent researcher for the new institutional economics school, commented that factors like market expansion, technology innovation, and investment enhancement for people all play a part in productivity growth. But how do we explain the continuation of poverty in many parts of the world once we know the causes of economic growth? The answer lies in human failure to undertake innovations to increase production. The institutional framework of a society creates incentives, which directly affect economic and political activity, and the institutional foundations for successful economic growth.

So, what is the root cause of increased productivity to motivate growth (human capital, technology, or national institutional foundation) is the subject of much debate among researchers. In addition, empirical studies have so far solely focused on the role of institutions and TFP as independent 
factors in the model, but have not emphasized the relationship between them to see how they interact with each other and what is the core of long-term growth. In the context of developing countries continuing to seek appropriate growth models to catch up with developed economies, and on the basis of the analytical framework of North and Thomas (1973), this paper attempts to find the answer to the question of how TFP, institutional quality, and the interactive variable between them impact on economic growth in Asian lowmiddle income, in an effort to contribute empirical evidence to the literature.

To this end, the paper is structured as follows. Section 2 reviews the literature on the impact of TFP and/or institution quality on economic growth. Section 3 introduces variables, model, methodology, and analyses empirical results. And Section 4 brings a conclusion and suggests some policy implications.

\section{Literature Review}

Felipe (1999) conducted the empirical literature on the impact of TFP on growth in East Asia region. The author found that the TFP growth estimates for the region vary significantly, even for the same country and time period and its impact on growth in East Asia is an activity subject to decreasing returns. Srinivasan (2005) examined TFP measurement and its contribution to economic growth in South Asia and China in the 1989-2003 period. The author found that well-functioning social and economic institutions are important for achieving sustained productivity growth.

Zhuang et al. (2010) investigated the relationship between public governance, institutional quality, and growth and income inequality in developing countries in Asia. By statistic description, the study uses World Bank's data set including six variables to measure institutional quality in the period of 1998-2008 to compare with income per capita and inequality indexes. The paper concludes that good governance should be pursued as the basic development goal in developing Asian economies, the effectiveness of government, quality of governance, and the rule of law is above average compared to overall countries in the world. The study also shows that during 1998-2008 these three factors grew faster than the world average, and this contributed significantly to the region's economic growth. Therefore, improving public governance in all areas is a potential basis for the nation's economic development strategy.

Park (2010) analyzed the changes in total factor productivity (TFP) growth in 12 Asian economies. By performing an empirical analysis using a comprehensive international data set, the paper investigates the main factors influencing TFP growth, particularly intangible factors such as human capital, and research and development capital. The resulting benchmark models from these empirical analyses are used to produce the long-term projection of TFP growth for the Asian economies for 2010-2030. Park (2012) assessed the importance of TFP growth to previous and later economic growth of 12 Asian economies. The author analyzes the previous growth model based on the calculation of TFP growth, studies the characteristics of TFP by estimating the TFP growth model, analyzes the factors affecting TFP growth and provides TFP growth forecast in long-term. By estimating panel data with fixed effects for 12 Asian countries over the period 1970-2007, the main findings are as follows: firstly, the growth model has shifted in the last decade to turn to a growth model based on productivity; secondly, catch-up effects have been a major driver of TFP growth over the past decades and the contribution of knowledge capital to TFP growth has finally increased in Hong Kong, Korea, Singapore and Taiwan in the most recent decade but stopped or weakened for other Asian economies; thirdly, the results predict strong TFP growth over the periods of 2010-2020 and 2020-2030 and suggest that productivity-based growth will continue in the long-term growth of Asian economies later.

Unlike most of the above studies, Law et al. (2013) examined the causal relationship between institutional quality and economic development in 60 countries in the periods of 1990-2008 and 1996-2008 by using Granger causality test. The study used both institutional International Country Risk Guide (ICRG) and World Governance Indicator (WGI) datasets. The estimation results indicate a two-way relationship between institution and economic development. This relationship varies with different stages of income per capita. Better institutional quality promotes economic development in highincome countries while economic development seems to improve institutional quality in lower-income countries.

Venard (2013) analyzed the relationship between institutional quality, corruption status, and economic development on a sample of 120 countries. The author makes three hypotheses: (i) high institutional quality framework is less corrupt; (ii) high institutional quality framework leads to high economic development; (iii) a less corrupted country will record higher growth. Based on these hypotheses, the study uses five indicators in the public governance index published by the WB to build an institutional quality framework divided into two groups of countries including poor institutional quality (have an average of indicators below 0) and high institutional quality (with an average score of indicators above 0). The author used Partial Least Squares (PLS) method to test data for these two groups in the years of 1998, 2001, 2004 and 2007. The results show that all the above assumptions are supported. High corruption and low institutional quality slow down economic development. In addition, the author argues that improving institutional quality and reducing corruption are more effective for 
economic development in countries with low institutional quality.

Azam and Emirullah (2014) empirically assessed the impact of corruption on the economic growth of nine selected Asia-Pacific countries in the period of 1985-2012. By using the methods of estimating fixed and random effects, the results show that corruption and inflation negatively affect economic growth in these countries. Therefore, the authors suggest that reducing corruption and controlling inflation should be one of the first priorities in implementing macro and public policies. Fayissa and Gill (2015) empirically investigated the impact of public administration on economic growth by using panel data for 37 Asian and Coastal countries during the 19962013 period. There are two empirical models with the dependent variables are GDP per capita and GDP growth, explanatory variables including institutions (derived by one of six indexes from WGI data), FDI, trade openness, total investment and aid. By using pooled Ordinary Least Squares (OLS), fixed effects (FE) and GMM methods, the authors demonstrate that public governance positively associated with economic growth in these countries. The implication is that institutional reforms need to be carried out comprehensively to lead to higher growth and escape poverty in some countries in the region.

Bhattacharjee and Haldar (2015) used FE and system Generalized Method of Moments (SGMM) to examine the determinants of economic growth in four major economies of South Asia with special emphasis on the role of institutions. They indicate that the two institutional measures, namely, voice and accountability and government effectiveness have appeared to be significant predictors of growth of selected South Asian countries. Tebaldi (2016) applied system GMM to examine the factors driving TFP growth in 63 countries from 1960 to 2011. The results indicated that initial conditions play a fundamental role on the dynamics of TFP: economies that started with lower TFP remained below initially better-positioned economies. This study finds evidence that institutional quality and openness are very important determinants of TFP growth. While better institutions promote technological progress and efficiency, globalization works as an important channel for knowledge and technological diffusion among nations, which fosters TFP growth.

Karimi and Daiari (2018) used GMM method to explore the relationship between institutions and economic growth in 10 ASEAN countries over the period 1996-2014. The empirical results confirms a positive relationship between a composite WGI and the economic growth in the selected ASEAN countries. This study also found that there is a bidirectional causality effect between the both variables. Most recently, Das and Upadhyay (2019) investigated the growth model in 15 Asian countries from the early 1970 s to 2014. The empirical indicates significant influence of human capital either directly on output growth or on growth through total factor productivity. The author found that the lower the development level of a country (i.e., a greater income gap), the greater the total factor productivity growth which therefore permits faster income convergence. There is some evidence of interaction between human capital and the income gap as well which leads to an even bigger impact of human capital on total factor productivity growth.

\section{Empirical Research}

\subsection{Data and Variables}

The paper used the dataset from the World Bank for the period 2000-2018 of 13 low-middle income countries including Bangladesh, Cambodia, India, Indonesia, Kyrgyr Republic, Lao PDR, Mongolia, Myanmar, Pakistan, Philippines, Timor-Leste, Uzbekistan and Vietnam. This research used real GDP per capita according to 2000 price to represent economic growth in all countries. GDP per capita is used to compare the level of development among countries and it is also an indicator to reflect life standards. Most empirical research concerning institutional impacts on economic growth and TFP on growth uses GDP per capita to derive economic growth. Other variables are included in the research models including (see Table 1):

Growth of total factor productivity-TFPG: According to the exogenous and endogenous growth theory, this is considered as the third factor affecting economic growth. There are many empirical studies that focus on the role of TFP to economic growth, in which the majority acknowledge that factor productivity is an important contributor to maintaining long-term growth and demonstrating the quality of economic growth as studied by Islam et al. (2006), Park (2012).

Institutional quality-INS: the institutional quality variables were used for the following reasons. First, to examine the impact of institutional quality on TFP growth. Some typical studies as Dreher et al. (2014), Krammer (2015), Bhattacharjee and Haldar (2015), Tebaldi (2016), Karimi and Daiari (2018), all demonstrated that institutional quality created a mechanism to encourage investment, physical capital accumulation, and human capital, leading to an increase in productivity from efficiency of these factors in production. Second, to use institutional quality variables in the growth model.

Government expenditure-GEXP: This variable includes administrative operations, the costs of maintaining and developing activities in the fields of health, education, science and technology. In the endogenous growth model, government spending plays an important role in increasing productivity and growth. The role of this variable is stressed in the latest study for the case of Vietnam (Nguyen, 2019) 
Total domestic investment-DINV: In the Cobb-Douglas production function, this is considered one of the main sources of capital. According to the models of economic growth, investment variables are important endogenous variables, affecting productivity and economic growth. Some typical papers use this variable in the empirical studies as Hamid and Pichler (2009), Ismihan and Metin-Ozcan (2009), Alani (2012), Erum et al. (2016).

Labour force-LABO: This is the basic factor in the growth model. Economic theories also make a clear argument about the difference between the amount of labor and the quality of labor (qualifications, skills) in influencing growth as well as increasing productivity. For instance, Miller and Upadhyay (2002), Das and Upadhyay (2019), Le et al. (2019) found that human capital as an important factor that positively influences TFP growth.

Trade openness-OPEN: A variable representing the openness policy of a nation's economy and foreign trade, calculated by the total values of export and import of goods and services by GDP. The endogenous growth models of Romer (1986), Lucas (1988) demonstrate that the increase in import-export activity positively impacts on productivity and economic growth. Tebaldi (2016), Das and Upadhyay (2019) affirmed the importance of this variable in the TFP impacts.

Inflation-INF: The consumer price index used to imply macroeconomic stability positively impacts on economic growth. Friedman (1977) found that this variable creates important impact on growth. Accordingly, its impact on economic growth can be negative or positive depending on the characteristics and circumstances of each country. The positive effect comes from the potential benefits of this variable in promoting savings and investment while negative effects are harmful to the economy because it increases the transaction costs of economic activities.

Infrastructure-TELE: This variable represents the development of infrastructure in a country, and is seen to have the effect on promoting and supporting economic activities. Many studies show that infrastructure made important contributions to economic growth. Esfahani and Ramirez (2003) found that infrastructure such as transportation, electrical energy and communications positively affected economic growth. The infrastructure may be proxied in several different ways as using the length of the highway in a square kilometer (Du et al., 2008), the length of the railway track (Kuzmina et al., 2014), fixed telephone subscribers over 100 people (Asiedu, 2002; Ancharaz, 2003; Nguyen, 2015), or using KW power consumption per capita.

Interactive variables between institutional quality and TFP growth-INS * TFPG: In theory, North and Thomas (1973), North (1990), Acemoglu et al. (2001) have argued about the relationship in which institutional changes lead to changes in productivity. Recent empirical studies such as Tebaldi and Elmslie (2013), Krammer (2015) demonstrated that institutional changes lead to changes in TFP. The paper puts interactive variables into the model to test how interactions between them affect economic growth.

Table 1: Variable description and source of data

\begin{tabular}{|c|l|c|}
\hline Signs & \multicolumn{1}{|c|}{ Descriptions } & Source \\
\hline TFPG & The percentage growth of TFP, calculated by Tornqvist index & $\begin{array}{c}\text { The conference board, total } \\
\text { economic database }\end{array}$ \\
\hline GDP & GDP per capita (2000 price), take the form of logarithm to derive for growth & World Bank \\
\hline INS & $\begin{array}{l}\text { Institutional quality is measured by six variables of governance indicators } \\
\text { set with values approximately from -2.5 to 2.5 } \\
\text { INS1: Control of Corruption } \\
\text { INS2: Government Effectiveness } \\
\text { INS3:Political Stability and Absence of Violence } \\
\text { INS4: Regulatory Quality } \\
\text { INS5: Rule of Law } \\
\text { INS6: Voice and Accountability }\end{array}$ & World Bank \\
\hline GEXP & Government Expenditure, by percentage of GDP & World Bank \\
\hline DINV & Total domestic investment, by percentage of GDP & World Bank, IMF \\
\hline OPEN & Trade open, by the total of export and import values, divided by GDP & World Bank \\
\hline LABO & Labor force, by percentage on total population & World Bank \\
\hline INF & Inflation rate, by percentage of the change of consumer price index & World Bank, IMF \\
\hline TELE & $\begin{array}{l}\text { A number of fixed subscribers on 100 people, take the form of logarithm to } \\
\text { derive for infrastructure }\end{array}$ & World Bank \\
\hline
\end{tabular}




\subsection{Model and Methodology}

\subsubsection{Model}

The analytical framework stems from the traditional Cobb-Douglas production function of an economy as follows:

$$
Y=A K^{\dot{a}} L^{1-\dot{a}}
$$

with $0<\alpha<1$

In which: $\mathrm{Y}$ is real GDP, $\mathrm{K}$ is domestic investment capital, $\mathrm{L}$ is labor force, $\mathrm{A}$ is TFP, $\alpha$ and $1-\alpha$ is elasticity coefficients of capital and labor, respectively.

Taking logarithm both sides, the equation (1) was written as:

$$
\log Y=\log A+\alpha \log K+(1-\alpha) \log L
$$

This equation was rewritten under the form of time sequence as:

$$
Y_{i, t}=A_{i, t}+\alpha A_{i, t}+(1-\alpha) L_{i, t}
$$

The equation (3) was used as a standard model in estimating growth regression.

The argument of North and Thomas (1973) considers institutions to be the core of the impact on other cumulative factors including the TFP thereby affecting economic growth. Typical studies by Miller and Upadhyay (2000), Loko and Diouf (2009) also identify factors affecting TFP including: institutions quality, trade openness, government spending, infrastructure, inflation, quality of labor, investment capital. Therefore, factor (A) in equation (3) is expressed by the equation as follows:

$$
\begin{array}{rlr}
A_{i, t}= & \beta_{0}+\beta_{1} I N S_{i, t}+\beta_{2} D I N V_{i, t}+\beta_{3} G E X P_{i, t}+\beta_{4} O P E N_{i, t} \\
& +\beta_{6} T_{E L E_{i, t}}+\varepsilon_{i, t}
\end{array}
$$

In which: INS is a measure of institutional quality; DINV is the total domestic investment; GEXP is a government expenditure; OPEN is the trade openness; INF is the inflation; TELE is a derivative variable for infrastructure.

The paper based on the new institutional economic theory when considering institutions as an endogenous factor in the growth model, thereby bringing both institutions and TFP into a common analytical framework to test simultaneously their effects on economic growth. This analysis provides further evidence of both the direct and indirect roles of institutions in promoting economic growth.

The model analysis framework also comes from equation (3). It can be written in the form of the regression equation as follows:

$$
\begin{aligned}
Y_{i, t}= & \alpha_{0}+\alpha_{1} \text { TFPG }_{i, t}+\alpha_{2} I N S_{i, t}+\alpha_{3} D_{I N V_{i, t}+\alpha_{4} G E X P_{i, t}} \\
& +\alpha_{5} L A B O_{i, t}+\alpha_{2} \text { OPEN }_{i, t}+\alpha_{7} I N S_{i, t}+\alpha_{2} \text { TELE }_{i, t}+\varepsilon_{i, t}
\end{aligned}
$$

In equation (5), factor (A) is considered as an independent variable directly affecting economic growth derived by the TFP growth rate, reflecting the efficiency technological progress. Domestic investment (DINV) and labor force (LABO) variables are derived for capital and labor which are the two main factors affecting output according to CobbDouglas production function. Inflation (INF) represents macroeconomic instability and government expenditure variables (GEXP), trade openness (OPEN), and infrastructure (TELE), which are variables affecting economic growth on the base of endogenous growth theory. Based on the above analysis, the study proposes an estimation model as follows:

$$
\begin{aligned}
\Delta Y_{i, t}= & \beta_{0}+\beta_{1} Y_{i, t-1}+\beta_{2} T F P G_{i, t}+\beta_{3} I N S_{i, t}+\beta_{4}\left(I S N * T F G G_{i, t}\right) \\
& +\beta_{5} Z_{i, t}+v_{i, t}+\varepsilon_{i, t}
\end{aligned}
$$

In which: $\Delta \mathrm{Y}_{\mathrm{it}}=\mathrm{Y}_{\mathrm{it}}-\mathrm{Y}_{\mathrm{it}-1}$ is the first-order difference of $\mathrm{Y}_{\mathrm{it}}$ which derives for economic growth; $\mathrm{Y}_{\mathrm{it}-1}$ on the right hand side of the equation represents the initial income level; TFPG $_{i t}$ is the explanatory variable for TFP growth; $\mathrm{INS}_{\mathrm{it}}$ is a proxy for institutional quality, including six indicators. The paper adds an interaction variable between institutions and TFPG denoted by INS $^{*}$ TFPG $_{\text {it }}$ to see if their interaction will have any additional effects on economic growth. $Z_{\text {it }}$ is a vector of control variables including total domestic investment, government expenditure, labor, trade open, inflation and infrastructure; is an unobservable error (country specific, constant over time) and is an error term.

\subsubsection{Methodology}

The paper uses the difference GMM estimation method because some of the following problems may arise and lead to the bias results of estimation:

(i) Due to the nature of macro variables, which usually have two-way effects. For instance, trade openness variables can be endogenous variables when it affects TFPG and vice versa TFPG also affects trade openness. Simultaneously, the factors that exist in errors can still affect trade openness, leading to the phenomenon of endogenous models. Some other variables in the model also have similar properties.

(ii) Some national characteristics are invariant over time such as geography, culture and anthropology, which may correlate with explanatory variables (fixed effects). These fixed effects are in the error of the experimental equations.

(iii) The presence of lag variables of $\mathrm{TFPG}_{\text {it -1 }}$ and $\mathrm{Y}_{\mathrm{it}-1}$ dependent variables leads to high autocorrelation and endogenous phenomena in estimating model. 
(iv) Panel data has a long observation period $(\mathrm{T}=19)$ and a number of countries $(\mathrm{N}=13)$.

All of these four problems can make OLS regression inconsistent and biased estimates. Thus, the estimated results will be ineffective or the endogenous problem cannot be thoroughly resolved by methods as FE, Random Effect (RE) or Two-Stage least squares (2SLS). The difference GMM regression method developed by Arellano and Bond (1991) can better handle these problems. This method uses appropriate lag of instrumented variables to create instrument variables. So, it is important to distinguish between the two. If the variables are expected to be endogenous (equivalent to non-strict exogenous), then arranged for the variable to be instrumented variables, and then only the lag value of these variables will be appropriate instruments. If the explanatory variables are identified as strictly exogenous as well as the added instrument variables (if any), then those are grouped into instrument variable. Variables that are considered to be strictly exogenous and lag values are all appropriate instrument variables. In this paper, the variables that are endogenous will be instrumented by taking the lag value. To ensure Sargan test, the number of selected instrument variables in principle should be less than or equal to the number of groups.

The appropriateness of instrument variables in estimating difference GMM panel data is tested through Sargan and Arellano-Bond statistics. Sargan test with null hypothesis $\mathrm{H}_{0}$ : the instrument variable is exogenous, meaning that it does not correlate with the error. So the $p$-value of Sargan statistics is as large as possible. The Arellano-Bond test is used to detect sequence autocorrelation at the first difference. Therefore, the results of the first order correlation test AR (1) need not be considered while the quadratic sequence autocorrelation AR (2) is tested based on the first difference sequence of errors to detect its first order of autocorrelation.

In summary, the GMM method uses appropriate lags of instrumented variables to create instrument variables. In addition, it also exploits the aggregated data of the table and does not bind the time series of table units in the panel data. This allows the use of an appropriate lags structure to exploit the different dynamic characteristics of the data.

\subsection{Regression Results}

\subsubsection{Descriptive Statistics}

The descriptive statistics are presented in Table 2 . The results show that the average income per capita in these developing countries is USD998 per year between 2000 and 2018. Meanwhile, the average TFP growth rate in these countries is $0.98 \%$ per year, a relatively low figure. In addition, in developing countries with low institutional quality, the average of all six variables are negative, especially in low-middle income countries. This data shows that this is a group of countries that need immediate and drastic measures to improve institutional quality, so that it is not a barrier to productivity and economic growth.

Table 2: Descriptive statistics of all variables in low-middle income countries

\begin{tabular}{|l|c|c|c|c|}
\hline \multicolumn{1}{|c|}{ Variables } & Mean & Standard Deviation & Min & Max \\
\hline GDP per capita & 998.01 & 522.0642 & 208.551 & 2637.192 \\
\hline TFPG & 0.9806 & 4.178463 & -22.17 & 22.605 \\
\hline Control corruption & -0.694 & 0.371205 & -1.582 & 0.4098 \\
\hline Government effectiveness & -0.538 & 0.356381 & -1.483 & 0.114 \\
\hline Political stability & -0.822 & 0.704371 & -2.803 & 0.6068 \\
\hline Law quality & -0.496 & 0.434193 & -2.158 & 0.3199 \\
\hline Rule of laws & -0.638 & 0.467156 & -1.682 & 0.3266 \\
\hline Voice and explanation & -0.582 & 0.576051 & -2.096 & 0.4815 \\
\hline Domestic investment & 21.19 & 6.313806 & 5.444 & 39.662 \\
\hline Government expenditure & 25.43 & 8.668068 & 10.02 & 49.737 \\
\hline Labour force & 59.61 & 6.354221 & 46.681 & 74.33 \\
\hline Trade openness & 22.39 & 8.631419 & 8.254 & 199.65 \\
\hline Inflation & 10.84 & 22.47611 & -2.419 & 421 \\
\hline Infrastructure & 6.975 & 7.50868 & 0.1255 & 35.087 \\
\hline
\end{tabular}


Table 3: Correlation coefficients matrix

\begin{tabular}{|c|c|c|c|c|c|c|c|c|c|}
\hline & GDP & TFPG & INS1 & DINV & GEXP & LABO & OPEN & INF & TELE \\
\hline GDP & 1.00 & & & & & & & & \\
\hline TFPG & $-.101^{* \star * *}$ & 1.00 & & & & & & & \\
\hline INS1 & $.613^{* *+*}$ & $-.071^{* * *}$ & 1.00 & & & & & & \\
\hline DINV & $.047^{*}$ & -.003 & $.072^{* * * *}$ & 1.00 & & & & & \\
\hline GEXP & $.488^{*+*}$ & $-.084^{*+* x}$ & $.303^{*+*}$ & .012 & 1.00 & & & & \\
\hline LABO & $.772^{* * *+}$ & -.001 & $.408^{*+*+}$ & $.217^{* * *}$ & $.421^{* * * *}$ & 1.00 & & & \\
\hline OPEN & $32^{* * *}$ & $.049^{*}$ & $.314^{* * * *}$ & $.146^{* * *}$ & $.301^{*+*}$ & $.413^{* * * t}$ & 1.00 & & \\
\hline INF & $-.051^{* *}$ & $-.062^{* *}$ & $-.012^{* * * t}$ & -.081 & .000 & -.007 & .029 & 1.00 & \\
\hline TELE & $.815^{* * *}$ & -.022 & $.463^{* * *}$ & $.126^{* * *}$ & $.543^{* * * *}$ & $.829^{* * *}$ & $.335^{* * *}$ & .034 & 1.00 \\
\hline
\end{tabular}

Note: The asterisk * ${ }^{* *}$ and ${ }^{* * *}$ denotes statistical significance at 10,5 and 1 percent levels, respectively

The correlation coefficient matrix between variables is shown in Table 3. The results show that, apart from inflation, all the remaining variables are correlated with economic growth at the significant level of at least $10 \%$. Accordingly, TFPG and INF are negatively correlated while all remaining explanatory variables are positively correlated with economic growth. All correlation coefficients between explanatory variables were lower than 0.8 , except for the correlation between TELE and GDP; TELE and LABO variables.

\subsubsection{Regression Results}

The estimated results are shown in Table 4. The values of the AR (2) and Sargan test are satisfied that the model overcomes the endogenous and sequence correlation, therefore, the estimated results are reliable to make analysis.
The GDP (-1) negatively impacts on economic growth with statistical significance of $1 \%$. TFP growth positively affects the GDP per capita growth in all six estimates. This result shows a high consistency with the paper's hypothesis on the positive role of TFP on economic growth. Similarly, the increase in productivity of an element or all of the inputs shows an increasing efficiency in the management and use of production factors, which will cause an increase in output on the same amount of input as before. This increase is considered as to be the quality of growth of the economy and contribute to sustaining long-term growth. The research results contribute to affirming the important role of TFP in the growth model, since then, there should be specific studies and modeling of the factors affecting TFP growth to demonstrate clearly for countries to adjust their economic development policies.

Table 4: Estimated results by the difference GMM

\begin{tabular}{|c|c|c|c|c|c|c|}
\hline Dependent variable -GDP & INS1 & INS2 & INS3 & INS4 & INS5 & INS6 \\
\hline GDP per capita (-1) & $-0.339^{* * *+}$ & $-0.421^{* * *}$ & $-0.213^{* * *}$ & $-0.215^{* * *}$ & $-0.360^{4 *+}$ & $-0.428^{*+*+}$ \\
\hline TFPG & $0.858^{* * *}$ & $0.615^{* * *}$ & $1.045^{* * *}$ & $1.186^{* * *}$ & $1.193^{*+*}$ & $0.545^{* * *}$ \\
\hline INS & $-17.811^{* *}$ & $-11.082^{* *}$ & $-9.224^{* \prime}$ & $-3.051^{* *}$ & -3.370 & $-7.751^{*}$ \\
\hline TFPG*INS & 0.522 & $0.258^{*+*}$ & $0.317^{4 *}$ & $0.901^{1 * *}$ & $0.809^{* * *}$ & $0.248^{* *+1}$ \\
\hline DINV & $1.366^{* * *}$ & $0.692^{* * *}$ & $0.356^{* * *}$ & $0.248^{* * *}$ & $0.691^{* * *}$ & $0.687^{x+*+}$ \\
\hline GEXP & 0.033 & -0.129 & 0.101 & 0.039 & -0.072 & -0.128 \\
\hline LABO & $4.179^{* * *+}$ & $5.887^{\text {t*t* }}$ & $2.809^{*+*}$ & $2.961^{\text {t*t+ }}$ & $5.107^{+* *+*}$ & $6.081^{* *+x}$ \\
\hline OPEN & 0.114 & $0.046^{* * *+}$ & $0.019 \%$ & $0.018^{* * *}$ & $0.027^{* * *}$ & $0.049^{* *+*}$ \\
\hline INF & $0.012^{m+*}$ & $0.131^{t+t}$ & $0.039 \%$ & $0.014^{*+*}$ & $0.046^{* *+*}$ & $0.028^{*+*+1}$ \\
\hline TELE & $-0.155^{*+*}$ & $-0.115^{\text {tw* }}$ & $-0.028^{* * *}$ & $-0.018^{* *}$ & $-0.084^{* *+*}$ & $-0.105^{\text {tat }}$ \\
\hline Obs. & 308 & 352 & 352 & 352 & 352 & 330 \\
\hline $\mathrm{AR}(2)$ test & 0.536 & 0.123 & 0.927 & 0.675 & 0.102 & 0.109 \\
\hline Sargan test & 0.129 & 0.214 & 0.228 & 0.197 & 0.195 & 0.208 \\
\hline
\end{tabular}

Note: The asterisk * ${ }^{* *}$ and ${ }^{* * *}$ denotes statistical significance at 10,5 and 1 percent levels, respectively 
In particular, in low-middle income countries, the institutional quality shows a significant negative effect on growth. This result can be explained by the following reason. First, according to the theory of underground economic sector, the activities of underground economic areas contribute significantly to economic growth. Therefore, with the poor institutional environment, the underground economic activities are more favorable, so if the governments improve their institutional reforms quickly and drastically, they can cause the operation of this area to decline, leading to a decrease in the output of the economy over a certain period. Second, because the institutional quality scores in these countries are very low, along with slow institutional reforms, the issuance of policies may only benefit certain groups of people in society who are closely tied with policymakers, and policy-makers can take advantage to make profit from their groups. Therefore, the institutional framework is not beneficial to the people, distorts economic activities, and restricts growth momentum. Good institutional quality leads to rapid growth, so transitioning and developing economies need to accelerate the process of reform to improve institutional quality.

Domestic investment, labor force, trade openness, and inflation have a positively effect, while infrastructure negatively impacts economic growth. Economic growth theories, typically endogenous growth models, identify capital and labor force as important endogenous inputs in promoting growth. Especially in developing countries, capital and labor are still the main factors to increase output. This effect occurs, not only in developing countries, but also in developed countries. The policies of economic opening, export promotion, and development of foreign trade activities will help developing countries to take advantage of labor advantages and absorb advanced technologies. The inflation positively affects growth, meaning that a reasonable inflation rate will stimulate growth in these developing countries. Infrastructure plays an important role in economic development. However, the estimated results show that infrastructure has a negatively effect on growth in developing countries. This may be due to reasons that the majority of infrastructure investments in developing countries are undertaken by the public sector, so the inspection and supervision of public investment projects are not transparent. So, it is unavoidable that the corruption and self-seeking interests of officials make the quality of the construction low and does not meet the interests of citizens and businesses. In addition, the construction and development of infrastructure do not stem from the interests of people and businesses, so they do not bring about the benefits and effectiveness as expected.

Specifically, the estimated results show that the interaction of institutional quality and TFPG positively impact economic growth with statistical significance at $1 \%$ for all six institutional variables. This new finding is also in line with the theory of institutional relations and TFP, which can create an enabling environment to boost productivity, or can also hinder productivity gains - either it is a barrier to the adoption and application of new technologies, or it creates profiteering behavior from the policy that depresses economic performance.

\section{Conclusion and Policy Implication}

The estimated results show that TFP growth and interaction variables significantly positive impact on GDP growth per capita in all estimates. This consistent finding contributes to strengthening the theory of institutions and TFP's role in economic growth. In particular, the interaction variable between INS and TFP creates additional positive impact on economic growth and this is a testament to the institutional importance. It is not only a causal factor affecting TFP in order to motivate growth but shows a direct role as an endogenous factor in the growth model.

Other explanatory variables as domestic investment, labor force and trade openness, all create positive effects on average GDP growth. This result is consistent with the arguments of neoclassical growth and endogenous growth models when determining that capital, labor, and economic openness are fundamental factors to promote economic growth. The empirical results show that the infrastructure negatively affects economic growth so the paper suggests to learn more about the role of this determinant in the case study.

Acemoglu and Robinson (2012) have convincingly demonstrated that the richness or poverty of a country is not due to geographical conditions, culture, etc., but what makes the difference is institutions. This is a clear argument on the decisive role of an institution in a country's economic development. In this study, institutional quality negatively impacts GDP growth in Asian low-middle income countries. In practice, that is an obstacle in the process of economic development for these countries. Therefore, the abovementioned goal that needs special attention in the above countries is to work towards effective institutions, which will help economic growth in the long term because of the following reasons. First, institutions play a guiding role, and create a framework for the organization and operation of the economy. Second, institutions have a role to control the resources in society. Third, institutions play an important role in maintaining a good government and reducing corruption. Last, but not least, institutions contribute to creating prerequisites for limiting market imperfections in the process of economic development.

\section{References}

Acemoglu, D., Johnson, S., \& Robinson, J. A. (2001). The colonial origins of comparative development: An empirical 
investigation. American Economic Review, 91(5), 1369-1401. http://www.jstor.org/stable/2677930

Acemoglu, D., \& Robinson, J. (2012). Why Nations Fail: The Origins of Power, Prosperity and Poverty. New York: Crown.

Alani, J. (2012). Effects of technological progress and productivity on economic growth in Uganda. Procedia Economics and Finance, 1, 14-23. https://doi.org/10.1016/S22125671(12)00004-4

Ancharaz, V. D. (2003). Determinants of Trade Policy Reform in Sub-Saharan Africa. Journal of African Economics, 12(3), 417443. https://doi.org/10.1093/jae/12.3.417

Arellano, M., \& Bond, S. (1991). Some tests of specification for panel data: Monte Carlo evidence and an application to employment equations. The Review of Economic Studies, 58(2), 277-297. https://doi.org/10.2307/2297968

Asiedu, E. (2002). On the Determinants of Foreign Direct Investment to Developing Countries: Is Africa Different?. World Development, 30(1), 107-119. https://doi.org/10.1016/ S0305-750X(01)00100-0

Azam, M., \& Emirullah, C. (2014). The role of governance in economic development: Evidence from some selected countries in Asia and the Pacific. International Journal of Social Economics, 41(12), 1265-1278. https://doi.org/10.1108/ IJSE-11-2013-0262

Bhattacharjee, J., \& Haldar, S. (2015). Economic growth of selected South Asian countries: Does institution matter? Asian Economic and Financial Review, 5(2), 356-370. DOI: 10.18488/journal. aefr/2015.5.2/102.2.356.370

Das, S., \& Upadhyay, M. (2019). Growth of Real GDP and Total Factor Productivity in Asia with an Emphasis on Malaysian Growth. Atlantic Economic Journal, 47, 391-413. DOI: $10.1007 / \mathrm{s} 11293-019-09642-5$

Dreher, A., Méon, P. G., \& Schneider, F. (2014). The devil is in the shadow. Do institutions affect income and productivity or only official income and official productivity? Public Choice, 158(12), 121-141. DOI: 10.1007/s11127-012-9954-8

Du, J., Lu, Y., \& Tao, Z. (2008). Economic institutions and FDI location choice: Evidence from US multinationals in China. Journal of Comparative Economics, 36(3), 412-429. http://www.sciencedirect.com/science/article/pii/S01475967(08)00022-X

Erum, N., Hussain, S., \& Yousaf, A. (2016). Foreign Direct Investment and Economic Growth in SAARC Countries. Journal of Asian Finance, Economics and Business, 3(4), 5766. https://doi.org/10.13106/jafeb.2016.vol3.no4.57

Fayissa, B., \& Gill, F. (2015). Revisiting the growth-governance relationship in developing Asian and Oceanic economies. Journal of Economics and Finance, 1(14). DOI: 10.1007/ s12197-015-9340-8

Felipe, J. (1999). Total factor productivity growth in East Asia: A critical survey. The Journal of Development Studies, 35(4), 1-41. DOI: $10.1080 / 00220389908422579$
Friedman, M. (1977). Nobel Lecture: Inflation and Unemployment. Journal of Political Economy, 85(3), 451-472.

Hamid, A., \& Pichler, J. H. (2009). Human Capital Spillovers, Productivity and Growth in the Manufacturing Sector of Pakistan. The Pakistan Development Review, 48(2), 125-140. DOI: $10.30541 / \mathrm{v} 48 \mathrm{i} 2 \mathrm{pp} .125-140$

Islam, N., Dai, E., \& Sakamoto, H. (2006). Role of TFP in China's Growth. Asian Economic Journal, 20(2), 127-159. https://doi. org/10.1111/j.1467-8381.2005.00208.x-i1

Ismihan, M., \& Metin-Ozcan, K. (2009). Productivity and Growth in an Unstable Emerging Market Economy: The Case of Turkey, 1960-2004. Emerging Markets Finance and Trade, 45(5), 4-18. https://doi.org/10.2753/REE1540-496X450501

Karimi, M.S., \& Daiari, E.H. (2018). Does Institutions Matter for Economic Development? Evidence for ASEAN Selected Countries. Iranian Economic Review, 22(1), 1-20. DOI:10.22059/ier.2018.65343

Krammer, S. M. (2015). Do good institutions enhance the effect of technological spillovers on productivity? Comparative evidence from developed and transition economies. Technological Forecasting and Social Change, 94, 133-154. https://doi. org/10.1016/j.techfore.2014.09.002

Kuzmina, O., Volchkova, N., \& Zueva, T. (2014). Foreign direct investment and governance quality in Russia. Journal of Comparative Economics, 42(4), 874-891. https://doi. org/10.1016/j.jce.2014.08.001

Law, S.H., Lim, T.C., \& Ismail, N.W. (2013). Institutions and economic development: A Granger causality analysis of panel data evidence. Economic Systems, 37(4), 610-624. DOI: 10.1016/j.ecosys.2013.05.005

Le, N.H., Duy, L.V.Q., \& Ngoc, B.H. (2019). Effects of Foreign Direct Investment and Human Capital on Labour Productivity: Evidence from Vietnam. Journal of Asian Finance, Economics and Business, 6(3), 123-130. https://doi.org/10.13106/ jafeb.2019.vol6.no3.123

Loko, B., \& Diouf, M. A. (2009). Revisiting the Determinants of Productivity Growth: What's New? IMF Working Papers, No.09/225.

Lucas, R. E. (1988). On the mechanics of economic development. Journal of Monetary Economics, 22(1), 3-42.

Miller, S. M., \& Upadhyay, M. P. (2002). Total factor productivity and the convergence hypothesis. Journal of Macroeconomics, 24(2), 267-286. https://doi.org/10.1016/ S0164-0704(02)00022-8

Nguyen, H.H. (2019). The Role of State Budget Expenditure on Economic Growth: Empirical Study in Vietnam. Journal of Asian Finance, Economics and Business, 6(3), 81-89. https:// doi.org/10.13106/jafeb.2019.vol6.no3.81

Nguyen, V.B. (2015). Effects of Institutional Quality on FDI in Provinces of Vietnam: Empirical Evidence Based on Differenced Panel GMM. Journal of Economic Development, 22(3), 26-45. DOI: 10.24311/jed/2015.22.3.04 
North, D. C., \& Thomas, R. P. (1973). The rise of the western world: A new economic history. Cambridge, UK: Cambridge University Press.

North, D. C. (1990). Institutions, institutional change and economic performance. Cambridge: UK: Cambridge University Press.

North, D.C. (2000). A Revolution in Economics. Chapter 4 in C. Menard (Eds.), Institutions, Contracts and Organizations: Perspectives from New Institutional Economics. Cheltenham, UK: Edward Elgar.

Park, J. (2010). Projection of Long-Term Total Factor Productivity Growth for 12 Asian Economies. Asian Development Bank Economics Working Paper Series, No.227.

Park, J. (2012). Total factor productivity growth for 12 Asian economies: The past and the future. Japan and the World Economy, 24, 114-127. https://doi.org/10.1016/j.japwor.2012.01.009

Romer, P. M. (1986). Increasing Returns and Long-Run Growth. The Journal of Political Economy, 94(5), 1002-1037.
Srinivasan, T.N. (2005). Productivity and Economic Growth in South Asia and China. The Pakistan Development Review, 44(4), 479-503. http://www.pide.org.pk/pdf/PDR/2005/ Volume4/479-503.pdf

Tebaldi, E. (2016). The dynamics of total factor productivity and institutions. Journal of Economic Development, 41(4), 1-25.

Venard, B. (2013). Institutions, Corruption and Sustainable Development. Economics Bulletin, 33(4), 2545-2562. Available at SSRN: https://ssrn.com/abstract=2340885

World Bank. (2018). World Bank DataBank. World Development Indicators. From http://databank.worldbank.org/data/databases. aspx

Zhuang, J., De Dios, E., \& Martin, A. L. (2010). Governance and institutional quality and the links with economic growth and income inequality: With special reference to Developing Asia. Asian Development Bank Economics Working Paper Series 193. 